\title{
DIFFERENCES REVEALED BY PAPER PARTITION CHROMATOGRAPHY BETWEEN THE GASTROPOD NAS SARIUS RETICULATUS (L.) AND SPECIMENS BELIEVED TO BE $N$. NITIDA (JEFFREYS)
}

\author{
By Dorothy M. Collyer \\ Fisheries Laboratory, Burnham-on-Crouch, Essex
}

(Plates I-III and Text-fig. I)

During studies of the bottom fauna of the Essex oyster grounds a gastropod of the family Nassidae was found to be common. This mollusc was provisionally identified as Nassarius reticulatus (L.), but showed some characteristics which closely resembled those of $N$. nitida (Jeffreys) (Mistakidis, I95I, p. I9). In view of the uncertainty of the identification of the Essex specimens and the fact that Jeffreys ( 1867, p. 350), in giving the variety nitida specific rank, had expressed misgivings, Dr H. A. Cole and $\mathrm{Mr}$ M. N. Mistakidis initiated a more detailed study of the taxonomy of the Essex material. Their current unpublished work tends to show that, on morphological grounds, the Essex material should be ascribed to the species $N$. nitida. As part of this investigation the writer was asked to see whether paper chromatography would reveal any consistent biochemical differences between the Essex material and specimens from Plymouth, where the local species had been definitely identified as $N$. reticulatus (L.) (Marine Biological Association, 1957). The fact that Nassarius found off North Wales resemble the Plymouth specimens morphologically, and are ascribed to the species reticulatus, was also utilized. The present report sets out the result of this biochemical study.

The usefulness of the technique of paper partition chromatography in the field of systematics was reviewed by Farris (1957), while a very useful review, comprehensive as regards zoological studies, has been made by Wright (I959) in the introductory section of his paper dealing with the biochemical specificity of snail mucus. A recent paper by Alston \& Turner (1959) gives further references, while work done on bacteria by several investigators has been outlined by Mattick, Cheeseman, Berridge \& Bottazzi (1956).

Judging from the results of the workers who have used this method, it would seem that, with certain reservations, the biochemical complex of each species does indeed produce its own characteristic pattern when chromatographically separated. Very good evidence for the validity of the method has been produced by Alston \& Turner (1959), who found that they could invariably distinguish Baptisia laevicaulis from B. viridis by chromatography; 
each gave a constant pattern, while hybrids gave many intermediate patterns. Further supporting evidence comes from work carried out at the National Institute for Research in Dairying and published in a series of papers (Mattick et al., 1956; Berridge, Cheeseman, Mattick \& Bottazzi, 1957; Cheeseman, Berridge, Mattick \& Bottazzi, I957; Gregory \& Mabbitt, I957 a, b; Mattick, Berridge, Cheeseman \& Mabbitt, 1957). These investigators found that, while different bacterial species gave different free amino-acid and peptide patterns, different strains of the same species gave substantially the same pattern; there were, however, some variations, less than those between species, due to age of culture or to composition of medium. Micks (1954) found chromatography useful in separating mosquito species, and Buzzati-Traverso \& Rechnitzer (1953) found the fluorescent and ninhydrin-positive patterns produced by fish muscle to be remarkably constant within a species, regardless of size or age of the individuals, while different species produced constantly distinct patterns, the differences being greater the more distantly related the species under comparison. Wright (I959) found constant patterns to be produced by mucus of several species of Lymnaea, but in some cases the extent of similarities of pattern did not appear to be correlated with degree of relationship between the species. Such a correlation was, however, indicated when foot tissue of Australian land snails was used (Kirk, Main \& Beyer, 1954). Further examples are to be found in the reviews to which reference has already been made.

From a study of all the available results, one is led to the general conclusion that each species produces its own characteristic chromatographic pattern; however, as has already been mentioned with respect to bacteria, it has also been found that individuals of the same species do not always produce exactly the same pattern. It is therefore essential that careful control in experimental methods and great caution in interpretation be exercised-a point made by both Farris (1957) and Wright (1959), in whose reviews further examples of such variation can be found. Different diets, and also starvation, affect the pattern in Sardinops caerulea (Farris, 1958), and the present paper describes an effect due to starvation. In Theba pisana three different diets had no effect on the pattern (Kirk et al., I954). Again, it is obvious that, when comparing a number of organisms by this method, the corresponding tissue must be taken from each, or, alternatively, as in the investigation using whole mosquitos, exactly the same combination of organs. Different tissues from the same organism will give different patterns. Such a study on Phaseolus vulgaris seedlings was described by Greenshields (1958). Wright (1959) found a seasonal variation in laboratory-bred Lymnaea palustris. Metamorphosis also causes changes, but it would be surprising if such a biochemical upheaval did not do so.

On the other hand, the possibility that two different species might produce the same pattern cannot be completely excluded, though on theoretical 
grounds a unique pattern for each species would be expected, provided that a wide enough range of compounds had been investigated.

\section{MATERIAL}

Specimens of the Essex form of Nassarius were collected from the Rivers Crouch and Roach, and N. reticulatus samples were collected off Plymouth. Those animals which were not used immediately on arrival were kept in running sea water in the laboratory. The glass tanks containing the two different forms were kept under identical conditions; where feeding was involved, individuals of the two batches were placed in the same tank after being marked on the shell with different coloured paints in the way described by Hancock \& Urquhart (1959). Mussels and crab meat were used for food.

For the supplementary investigation involving a small number of North Wales specimens, the animals were collected at Rhoscolyn, Anglesey.

Littorina were obtained from the Thames estuary and the Crouch.

The tissue used was that of the posterior end of the foot. Differences in the chemical composition of this organ are likely to correspond with true differences in body composition, rather than merely to reflect recently absorbed substances. The piece of tissue was washed in distilled water immediately after detachment, and prepared at once for paper chromatography.

\section{CHROMATOGRAPHIC METHODS}

Whatman No. $3 \mathrm{MM}$ chromatography paper was used. Sheets $42 \mathrm{~cm}$ wide were divided into eleven columns for the main investigation; some of the preliminary tests were made on narrower sheets. Length from start-line to base was also $42 \mathrm{~cm}$. The descending technique was employed.

In the method finally adopted, about $5 \mathrm{mg}$ foot tissue was used from each individual. Each column on the paper represented a different individual, and the tissue sample was applied to the start-line as a streak about $1 \cdot 5 \mathrm{~cm}$ long, centrally in the $3.8 \mathrm{~cm}$ wide column. The paper was placed on clean glass and the tissue squashed in well by means of the flat base of a small specimen tube. The tissue streaks were thoroughly dried in a stream of hot air. In preparing papers for examination by the ultra-violet method, I5-40 $\mathrm{mg}$ of tissue were crushed and extracted in a very small volume of hot $70 \%$ ethanol. The extract was applied to the start-line and dried.

The solvent used was that found most suitable for a similar investigation on land snails by Kirk et al. (I954); i.e. $n$-butanol: acetic acid: water (I00:22: $50 \mathrm{v} / \mathrm{v})$. No other solvent mixture was tried.

Preliminary experiments were made to ascertain the time necessary for maximum separation without loss of ninhydrin-positive or ultra-violet fluorescing material from the bottom of the paper. A satisfactory time was found to be $30-40 \mathrm{~h}$ according to room temperature, there being no temperature control.

Different methods were tried for the examination of the dried papers. The most useful method was found to be the application in the form of a spray of 
$0.1 \%$ ninhydrin in water-saturated butanol; the paper was then redried in a warm air stream and further heated at $100^{\circ} \mathrm{C}$ for 10 min. Examination in ultra-violet light $(3660 \AA)$, which was tried as an alternative method, revealed little until refinements were made in the application of the tissue material to the paper, as described above. Then, on recently heated papers, moderately well defined spots could be observed, following a pattern very suggestive of the ninhydrin-positive pattern. The fluorescent spots were outlined in pencil, and the papers then treated by the preceding method for revelation of ninhydrin-positive substances. Very well formed spots appeared, exactly coinciding with the marked fluorescent areas, which would therefore seem to be due solely to amino-acids. Although the method of applying tissue substances as an alcoholic extract resulted in much sharper spots, this was not used for the main investigation. The greater time involved was not felt to be justified, as the revealed ninhydrin-positive pattern was the same in both cases. The production of denser, better defined spots was undoubtedly due to the fact that a larger quantity of the active substances was applied to a smaller area of paper in the form of an extract than as whole tissue, the aminoacids therefore running in higher concentrations to smaller areas.

\section{PRELIMINARY EXPERIMENTS}

Preliminary experiments were planned first to throw light upon the more serious of the two points of doubt outlined above concerning the reliability of the technique, in so far as it affected this investigation. It was essential to know the extent of individual variation within an apparently homogeneous batch, so before attempting to compare Essex with Plymouth specimens of Nassarius, the variability within the Essex form was investigated. The effects on the ninhydrin-positive pattern of $(a)$ size of individual, (b) exact location of collection, and (c) starvation versus feeding, were ascertained.

The size of the individual had no effect on the chromatographic pattern, the only exception to this being that with very small individuals one or two of the pattern spots were sometimes difficult or impossible to see. The amount of tissue which could be taken from these specimens without encroaching on other organs was considerably smaller than the standard amount, and the chromatographic result was very probably due to the use of insufficient material and not to any real difference. As confirmation of this, a similarly small amount of tissue from a large individual was chromatographed, producing the same effect, which was therefore ignored; but very small specimens were not used in the comparative work.

Individuals differing from one another only in that they were collected from four different locations in the Essex rivers exhibited no differences in pattern. 
Duration of starvation, however, had an appreciable effect on the ninhydrin-positive substances of the foot tissue. Preliminary studies established that a consistent pattern was produced by different individuals from the same area when recently fed; and that a different but related pattern, equally reproducible, resulted from individuals which had been starved. Short periods without food resulted in intermediate patterns, as the changes occurring during starvation were due to the gradual disappearance or reduction of certain of the spots. The changes, which are referred to in greater detail in the next section, were reversible, even after prolonged starvation.

The theory that two definitely different species always produce different chromatographic patterns-identical patterns always indicating individuals of the same species-invited exploration, but could obviously provide an unlimited subject of study. As, in fact, the two forms of Nassarius did not produce identical patterns, this, the second point of doubt referred to above, was not very relevant to this investigation. However, tests were made to assess the degree of difference which might be encountered between species of two genera which were neither very closely nor too distantly related, and the results obtained may be of sufficient interest for inclusion here. Littorina littorea (L.) was selected as a readily obtainable marine gastropod of the same order of size as Nassarius. This species produced a consistent pattern which did not vary with the size of the animal, the place of collection, or with starvation, and which, though it also had much in common, differed distinctly from the Nassarius pattern. The Littorina pattern is described on p. 69I.

\section{CHROMATOGRAPHIC COMPARISON BETWEEN ESSEX AND PLYMOUTH SPECIMENS}

Because duration of starvation had been found to have an appreciable effect on the ninhydrin-positive substances of the foot tissue, the main experiments involving comparisons between the Plymouth and Essex specimens were planned to follow changes over a period of time after removal from their natural habitats. Specimens starved for a known period were used and also some which had subsequently been fed. In this way it was hoped that the immediate effects due to differences in the two natural environments would be eliminated, and that any differences revealed would therefore be of genetic origin.

Also with the aim of equalizing as many factors as possible, the collections of a sample at Plymouth and one from the River Crouch were made on the same day. Both samples were similarly boxed, and unpacked at the same time when the Plymouth specimens arrived at Burnham-on-Crouch 2 days later. These exactly parallel specimens were used for many of the chromatograms, including those shown in Pl. I, fig. 2 and Pl. II, fig. 2. When applying the 
prepared tissue or extract to the paper, material representing Plymouth individuals was always placed in columns alternating with those occupied by material from Essex specimens.

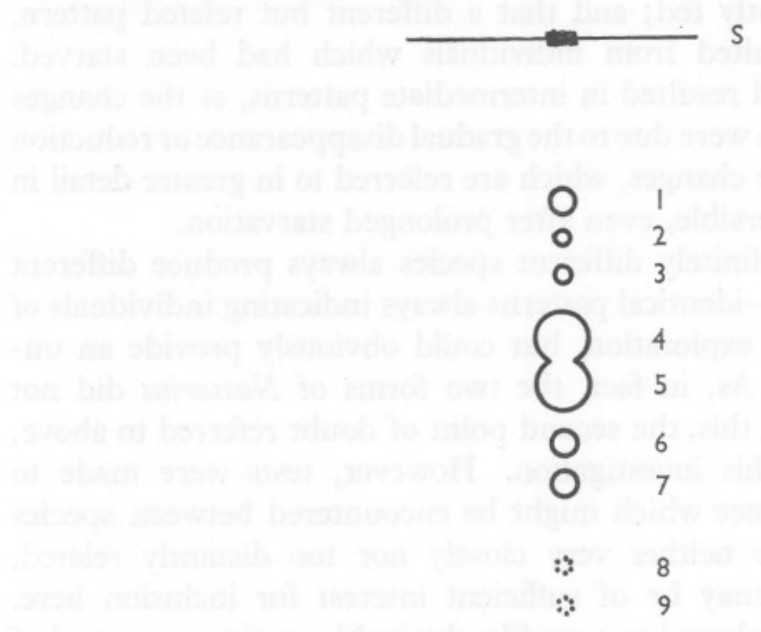

Text-fig. I. Diagrammatic representation of Nassarius ninhydrin-positive pattern, showing the numbering of spots ( $\mathrm{I}$ to 9 ) as used in the text. S, start-line and insoluble part of applied tissue.

As the solvent front reached the edge of the paper after the elapse of about one-third of the optimum development time, no $R_{F}$ data are available. To facilitate the description of results, the ninhydrin-revealed spots have been numbered, beginning with the one running most slowly. Reference should be made to Text-fig. I. Spots 6 and 7 proved to be useful 'markers', being quite constant in all the Nassarius and Littorina specimens. As the solvent did not flow at the same rate at all points across the width of the paper, this was a valuable feature.

No attempt was made to identify the substances, presumed to be aminoacids, responsible for the ninhydrin-positive pattern. Spot 5 was bluish purple on fresh chromatograms, the remaining spots being shades of reddish purple. Spot I remained as a faint brown spot months after the others had completely faded. It appeared brownish purple on fresh chromatograms when held up to the light. It was also found to react differently from the others in that its original purple colour turned blue when the chromatograms were stored with papers which had been sprayed with $p$-anisidine hydrochloride. Unsprayed chromatograms viewed in ultra-violet light showed Spot 4 as a slightly more bluish fluorescence than the others.

The results are illustrated in Pls. I-III. These chromatograms are necessarily only a selection, as many others were run, but the results were strikingly reproducible. In all, the number of individuals used for this work, including 
preliminary experiments, amounted to: Essex specimens of Nassarius, I88; Plymouth specimens, I28; North Wales specimens, II; Littorina, 20. The following points become clear from the study of these and other ninhydrinsprayed chromatograms.

Spot I

Essex Consistently present, not diminishing with starvation.

Plymouth Never as well marked as in Essex specimens. Disappeared gradually on starvation. Reappeared after feeding.

Spot 2

Behaviour not consistent enough for use in separation. Often the first spot to disappear in starving Essex specimens, though it sometimes persisted for a considerable time. Disappeared quickly in starving Plymouth specimens, and was never so obvious in a Plymouth specimen as in a parallel Essex one.

\section{Spot 3}

Essex Disappeared very slowly during starvation, reappearing after feeding.

Plymouth Behaved like Spot $\mathrm{I}$.

\section{Spots 4 and 5}

Essex 5 larger than 4,4 becoming even less evident during starvation, while 5 remained constant.

Plymouth 4 and 5 sometimes equal or nearly equal; but more usually 4 was distinctly larger than 5, this invariably indicating a Plymouth individual. Effect of starvation slight, being seen as a tendency for 4 to be distinctly larger than 5 in a higher proportion of fresh than starved specimens.

The proportions of the double spot which should be allocated to 4 and 5 respectively were much more readily seen in the original chromatograms, where the different shades of reddish and bluish purple could be easily distinguished, than in photographs. There was some evidence that further development might have divided Spot 5, and possibly also Spot 4, into more than one component. In particular, in well developed chromatograms, a small faster-running area seemed to be separating from the large main part of Essex Spot 5. When alcoholic extracts were chromatographed, ninhydrin-revealed Spot 4 was relatively more evident, Spots 4 and 5 appearing nearly equal in Essex specimens and Spot 4 (appearing to consist of two components) always distinctly larger than 5 in Plymouth specimens.

\section{Spots 6 and 7}

Essex and Plymouth. Consistently present.

\section{Spots 8 and 9}

These two spots were so faint that they could not be used critically, and were often allowed to run off the paper. They had begun to disappear from some individuals after I week without food. 


\section{CHROMATOGRAPHIC PATTERN GIVEN BY NORTH WALES SPECIMENS}

As the chromatographically different Plymouth and Essex Nassarius differed both morphologically and in their area of origin, a desirable supplementary investigation was a chromatographic comparison between batches of the $N$. reticulatus form from widely separated areas representing somewhat different habitats. To this end a few North Wales specimens were run parallel to Essex specimens in the same way that the Plymouth ones had been. Tissue squashes of the North Wales specimens were made by the standard technique soon after the animals were taken from the sea, and the papers were dried thoroughly and stored until tissue from similarly fresh Essex specimens had been applied to alternate columns of the same papers. Experience with Essex animals had shown that, when kept thoroughly dry, storage at this stage had no effect on the chromatographic pattern, and this fact was also mentioned by Wright (1959), and by Enge \& McKee (1959). The pattern produced by the North Wales specimens could not be distinguished from that of Plymouth specimens which had been used as soon as received, but was readily distinguishable from the parallel Essex pattern (P1. I, fig. I). North Wales specimens were not chromatographed after periods of starvation.

\section{EXPLANATION OF PLATES I-III}

Ninhydrin-sprayed chromatograms, showing patterns produced by the foot tissue of specimens of Nassarius and Littorina littorea. Alternate columns of all chromatograms, except that shown in Pl. III, fig. 2, represent Nassarius individuals from Essex and Plymouth (or North Wales), respectively. The letters ' $E$ ', ' $P$ ' and ' $W$ ' have been inserted beneath the columns to indicate the place of origin of each specimen.

\section{Plate I}

Fig. I. Samples, taken shortly after collection, from Essex (E) and North Wales (W) specimens. The North Wales pattern shown here was identical with that of Plymouth specimens used as soon as received.

Fig. 2. Samples taken I week after collection, starved. Chromatograms of starved specimens sampled 2 weeks after collection were very similar in appearance to this.

Plate II

Fig. I. Plymouth $(\mathrm{P})$ specimens starved $9 \frac{1}{2}$ weeks; Essex (E) specimens starved $8 \frac{1}{2}$ weeks. (Duration of starvation probably sufficient to allow the difference of one week to be ignored.)

Fig. 2. Samples taken after 3 weeks' starvation and subsequent feeding.

\section{Plate III}

Fig. I. Plymouth specimens starved $10 \frac{1}{2}$ weeks, Essex specimens starved $9 \frac{1}{2}$ weeks, both batches subsequently fed.

Fig. 2. Littorina littorea (left-hand column) and Essex Nassarius (remaining columns). In this preliminary test the paper was somewhat overloaded, resulting in rather pronounced streaks between the spots. 

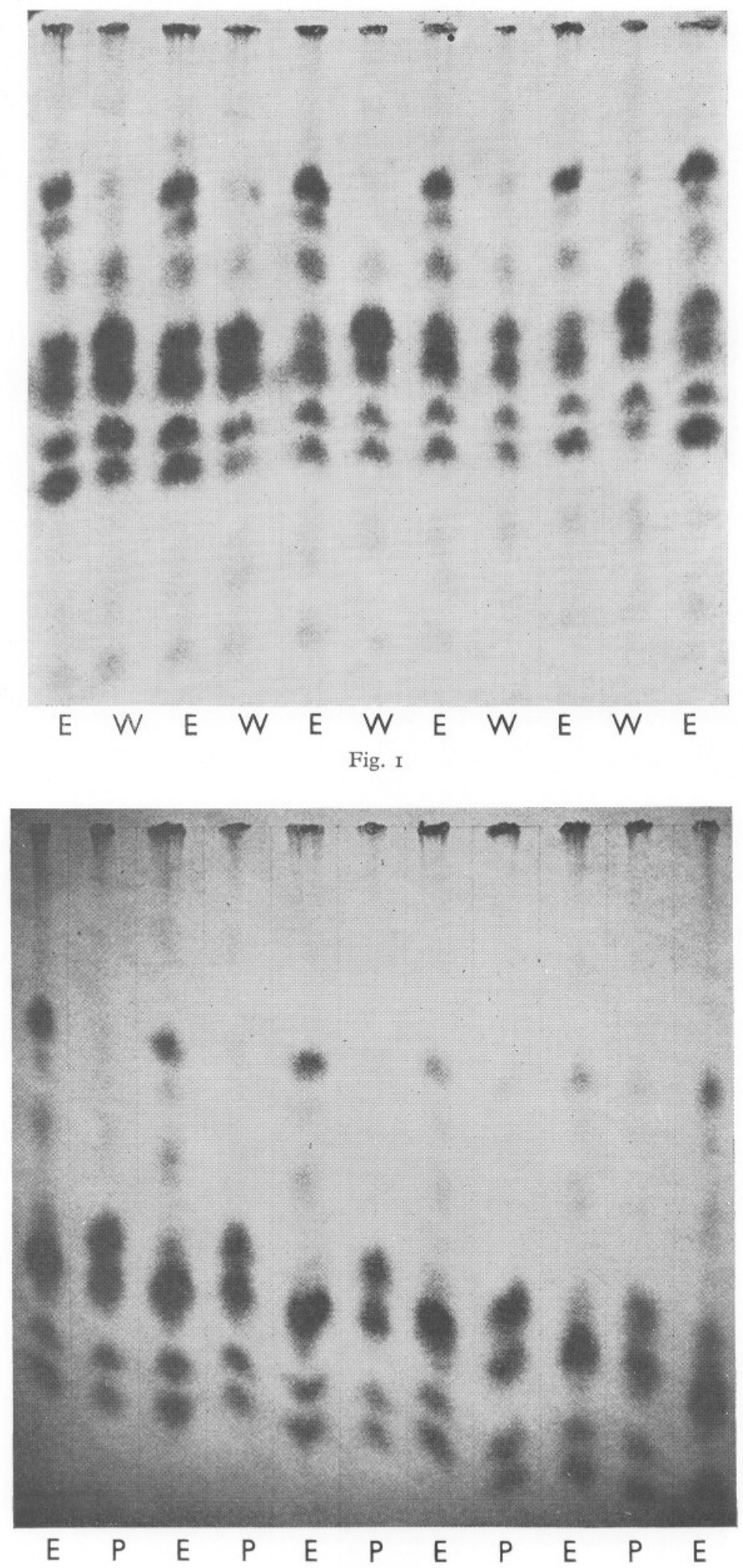

Fig. 2 


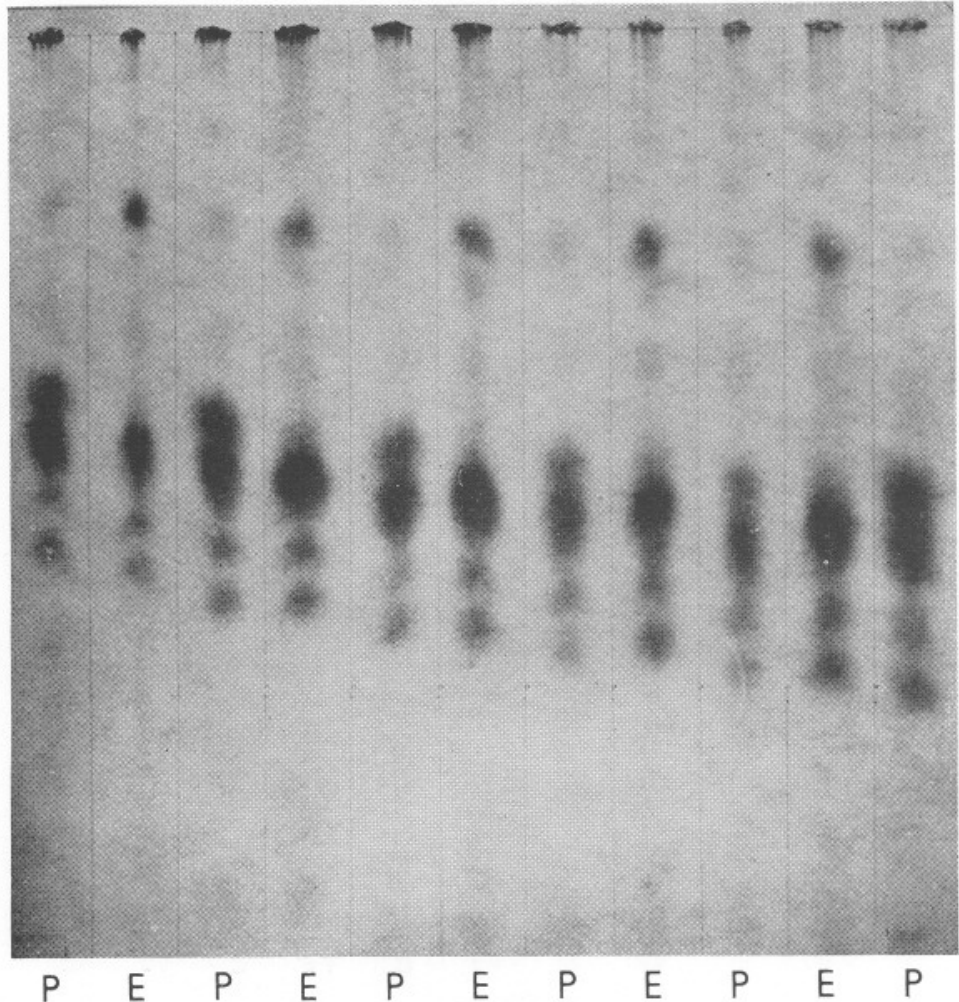

Fig. I

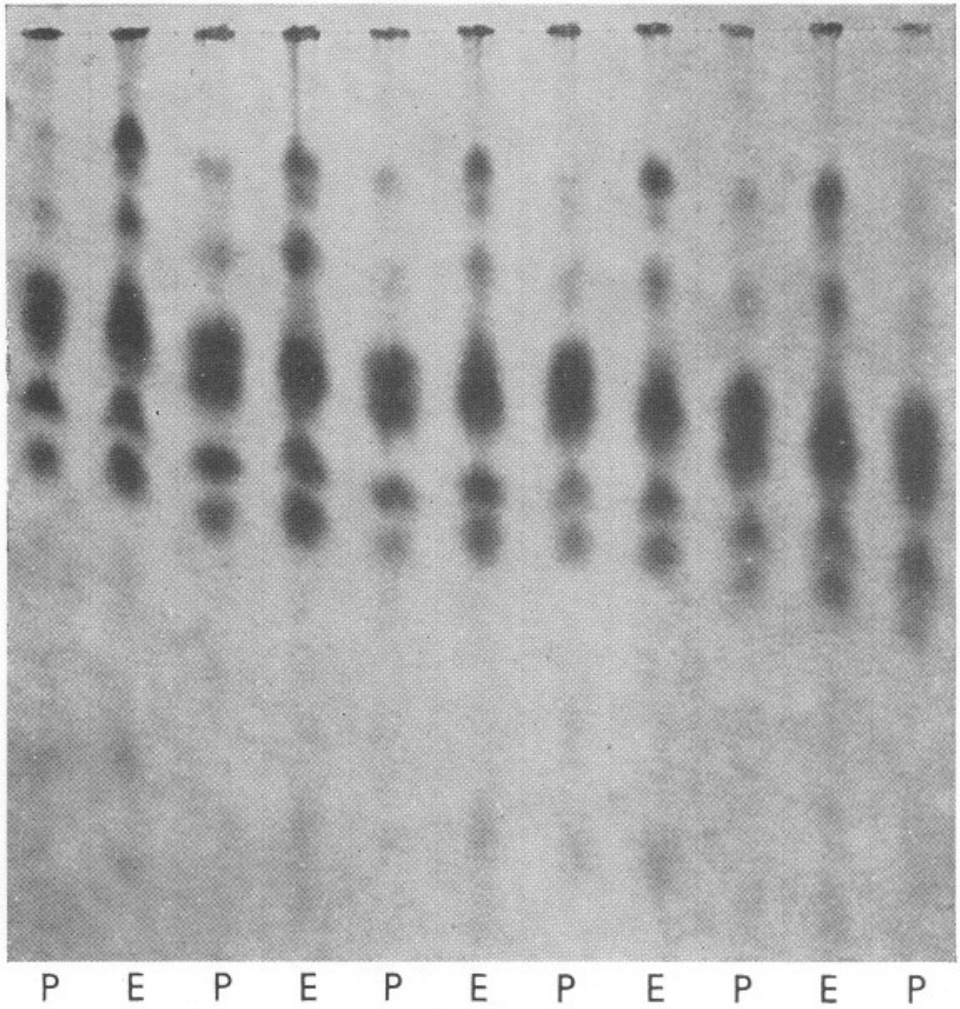

Fig. 2 
J. MAR. BIOL. Ass. U.K., 4I (3)

Collyer. PlAte III

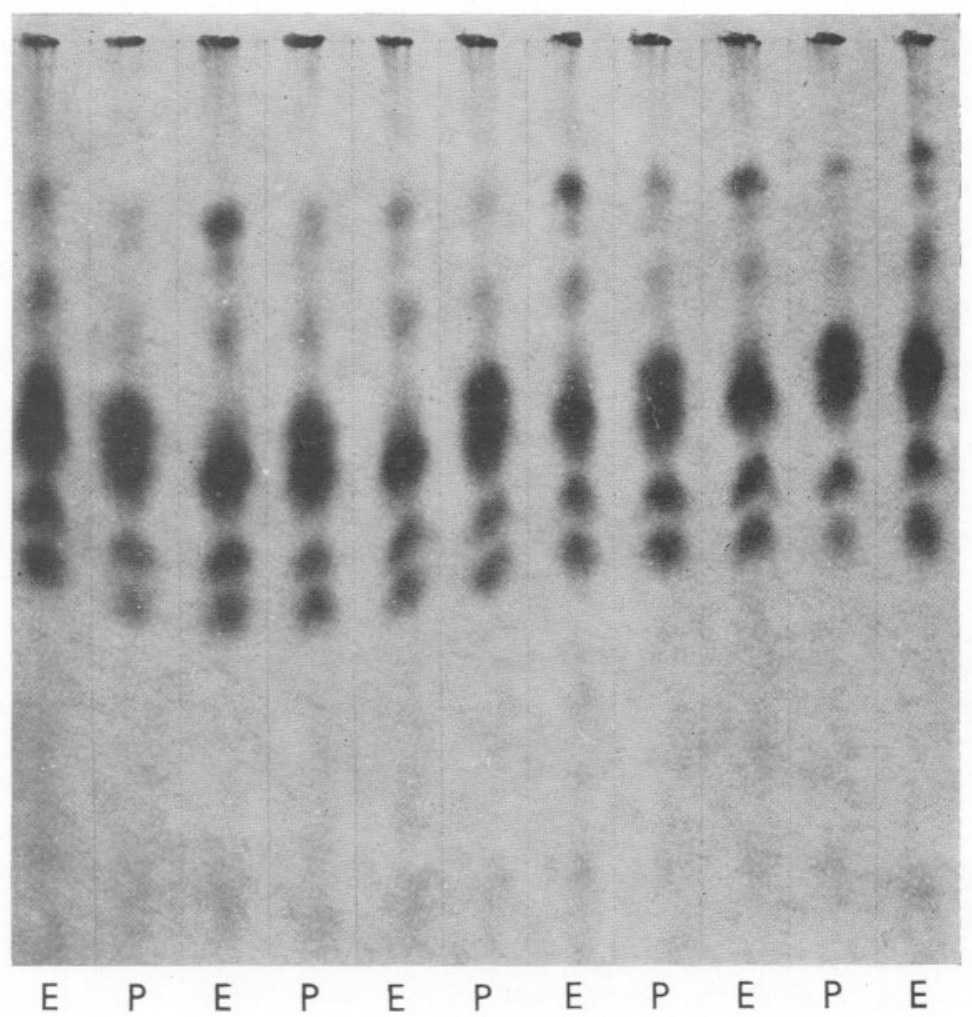

Fig. I

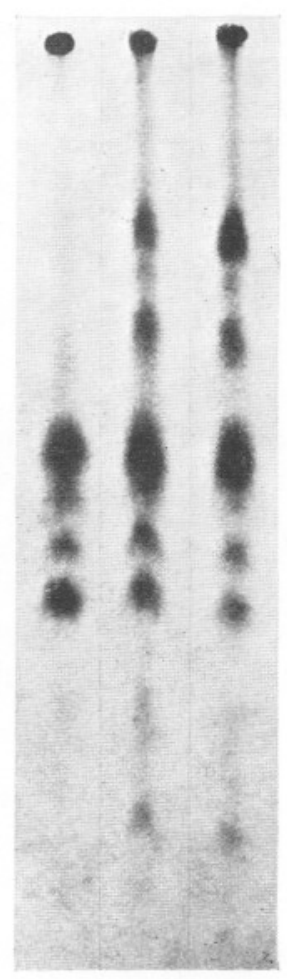

Fig. 2 
also to Mr P. J. Warren for taking the photographs; and to Dr L. Fowden of University College, London, for allowing me to use his ultra-violet lamp and for advice on the preparation of chromatograms for the ultra-violet method of examination. Special thanks are also due to Mr Simpson for most helpful criticism at the manuscript stage.

\section{SUMMARY}

The ninhydrin-positive patterns produced by chromatography of foot tissue of Nassarius reticulatus from Plymouth and North Wales and of specimens of Nassarius from Essex were established. The similarities and differences between the two are described and the consistent differences found are considered to be indicative of genetic differences between the specimens from Essex and those from the other two areas. The only factor found to affect the otherwise remarkably reproducible pattern given by individuals from the same area was the degree of starvation; the effect was reversible. The pattern given by another marine gastropod, Littorina littorea (L.), is also described. Reference is made to the potentialities of the technique.

\section{REFERENCES}

Alston, R. E. \& TURNER, B. L., 1959. Applications of paper chromatography to systematics: recombination of parental biochemical components in a Baptisia hybrid population. Nature, Lond., Vol. I84, pp. 285-6.

Berridge, N. J., Cheeseman, G. C., Mattick, A. T. R. \& Bottazzi, V., 1957. The differentiation of bacterial species by paper chromatography. II. Lactobacilli and Streptococci; the effect of age of culture. F. appl. Bact., Vol. 20, pp. 195-204.

Buzzati-Traverso, A. A. \& Rechnitzer, A. B., i953. Paper partition chromatography in taxonomic studies. Science, Vol. II7, p. 58.

Cheeseman, G. C., Berridge, N. J., Mattick, A. T. R. \& Bottazzi, V., 1957. The differentiation of bacterial species by paper chromatography. III. An examination of the Lactobacillus casei-plantarum group. F. appl. Bact., Vol. 20, pp. 205-17.

ENGE, K. \& MCKeE, J. S. McK., I959. Tests of the methods by which paper chromatography of fish muscle can be used as a taxonomic aid. Nytt. Mag. Zool., Vol. 8, pp. 34-6.

FARRIS, D. A., 1957. A review of paper chromatography as used in systematics. Spec. sci. Rep. U.S. Fish and Wildl. Serv., Fisheries No. 208, pp. 35-8.

- 1958. Diet-induced variation in the free amino acid complex of Sardinops caerulea. F. Cons. int. Explor. Mer, Vol. 23, pp. 235-44.

GREENSHIELDS, R. N., I958. A chromatographic method for studying simple compounds in plants. Nature, Lond., Vol. I8I, pp. 280-I.

GREGORY, M. \& MABBITT, L. A., I957a. The differentiation of bacterial species by paper chromatography IV. An examination of the Micrococci, with special reference to the influence on the chromatograms of medium and age of culture.
f. appl. Bact., Vol. 20, pp. 218-25.

Preliminary examination of the of bacterial species by paper chromatography V.

Preliminary examination of the Micrococci. $\mathcal{F}$. appl. Bact., Vol. 20, pp. 226-33. 
Hancock, D. A. \& URquHaRT, A. E., I959. Methods for marking whelks (Buccinum undatum L.). F. Cons. int. Explor. Mer, Vol. 24, pp. 494-6.

JefFreys, J. G., I867. British Conchology, Vol. 4. London: Van Voorst.

KIRK, R. L., MAIN, A. R. \& BEYER, F. G., I954. The use of paper partition chromatography for taxonomic studies of land snails. Biochem. F., Vol. 57, pp. 440-2.

Marine Biological Association, 1957. Plymouth Marine Fauna, 3rd Ed. Plymouth.

Mattick, A. T. R., Berridge, N. J., Cheeseman, G. C. \& Mabbitt, L. A., 1957. The differentiation and classification of bacteria by paper partition chromatography. F. gen. Microbiol., Vol. 17, Proc. Soc. gen. Microbiol., p. iii.

Mattick, A. T. R., Cheeseman, G. C., Berridge, N. J. \& Bottazzi, V., i956. The differentiation of species of Lactobacilli and Streptococci by means of paper partition chromatography. F. appl. Bact., Vol. 19, pp. 310-21.

MICKS, D. W., I954. Paper chromatography as a tool for mosquito taxonomy: the Culex pipiens complex. Nature, Lond., Vol. I74, pp. 217-18.

Mistakidis, M. N., I95I. Quantitative studies of the bottom fauna of Essex oyster grounds. Fish Invest., Lond., Ser. 2, Vol. 17, No. 6.

WRIGHT, C. A., I959. The application of paper chromatography to a taxonomic study in the molluscan genus Lymnaea. F. Linn. Soc. (Zool.), Vol. 44, pp. 222-37. 